\title{
Interleukin-8: A potent promoter of angiogenesis in gastric cancer
}

\author{
JUN SHI and PIN-KANG WEI \\ Department of Traditional Chinese Medicine, Shanghai Changzheng Hospital, The Second Military Medical University, \\ Shanghai 200003, P.R. China
}

Received January 22, 2015; Accepted November 30, 2015

DOI: $10.3892 / \mathrm{ol} .2015 .4035$

\begin{abstract}
Angiogenesis is a critical process in the development of tumor malignancy and occurs at various stages of tumor progression. Interleukin-8 (IL-8) is a pro-angiogenic factor produced by tumor-infiltrating macrophages that has been revealed to facilitate the development of angiogenesis in various cancers. However, whether IL-8 activates angiogenesis in gastric cancer remains unclear. The present study investigated the effect of IL- 8 on the migration and canalization capacities of human umbilical vein endothelial cells (HUVECs). In addition, the protein and messenger RNA (mRNA) expression of selected angiogenesis markers, consisting of vascular endothelial growth factor (VEGF)-A, VEGF receptor (VEGFR)-1 and VEGFR-2, were assessed in the HUVECs. The HUVECs were co-cultured with human gastric cancer SGC7901 cells and exposed to various concentrations of IL-8 $(0,0.2,0.5,0.8$ and $1.0 \mathrm{ng} / \mathrm{ml})$. The migration and canalization abilities of the cells were detected by Transwell chamber and tube formation assays. Protein expression was detected using immunofluorescence and western blot analysis, and mRNA levels were assessed using reverse transcription quantitative polymerase chain reaction. The protein and mRNA levels of VEGF-A, VEGFR-1 and VEGFR-2 were measured in HUVECs cultured for $24 \mathrm{~h}$. IL- 8 at concentrations of $0.5,0.8$ and $1.0 \mathrm{ng} / \mathrm{ml}$ significantly promoted HUVEC cell migration $(\mathrm{P}=0.005, \mathrm{P}=0.001$ and $\mathrm{P}<0.001$, respectively) and tube formation $(\mathrm{P}=0.039, \mathrm{P}=0.003$ and $\mathrm{P}<0.001$, respectively). IL-8 at concentrations of $0.2,0.5$, 0.8 and $1.0 \mathrm{ng} / \mathrm{ml}$ significantly elevated the protein levels of VEGF-A $(\mathrm{P}<0.001)$ and VEGFR-2 $(\mathrm{P}=0.034, \mathrm{P}<0.001$, $\mathrm{P}<0.001$ and $\mathrm{P}<0.001$, respectively). IL- 8 at concentrations of 0.8 and $1.0 \mathrm{ng} / \mathrm{ml}$ significantly elevated the protein levels of VEGF-1 $(\mathrm{P}=0.037$ and $\mathrm{P}=0.002$, respectively). Similarly, IL-8 at concentrations of $0.5,0.8$ and $1.0 \mathrm{ng} / \mathrm{ml}$ significantly
\end{abstract}

Correspondence to: Professor Pin-Kang Wei, Department of Traditional Chinese Medicine, Shanghai Changzheng Hospital, The Second Military Medical University, 415 Fengyang Road, Shanghai 200003, P.R. China

E-mail: czzyk73408@163.com

Key words: interleukin-8, angiogenesis, gastric cancer, vascular endothelial growth factor-A, vascular endothelial growth factor receptor-1, vascular endothelial growth factor receptor-2 upregulated the mRNA levels of VEGF-A $(\mathrm{P}=0.046$, $\mathrm{P}=0.001$ and $\mathrm{P}<0.001$, respectively) and VEGFR-1 $(\mathrm{P}=0.042$, $\mathrm{P}<0.001$ and $\mathrm{P}<0.001$, respectively). IL- 8 at concentrations of $0.2,0.5,0.8$ and $1.0 \mathrm{ng} / \mathrm{ml}$ significantly upregulated the mRNA levels of VEGFR-2 $(\mathrm{P}=0.003, \mathrm{P}=0.005, \mathrm{P}<0.001$ and $\mathrm{P}<0.001$, respectively). In conclusion, IL- 8 may be a potent promoter of angiogenesis in gastric cancer.

\section{Introduction}

Gastric cancer is one of the most aggressive tumors, with 951,594 cases diagnosed worldwide in 2012. Furthermore, gastric cancer was the third leading cause of cancer-associated mortality worldwide in 2012, accounting for 723,027 mortalities $(1,2)$. Notably, the age-standardized incidence rates for gastric cancer are approximately six times higher in Eastern Asia when compared with the USA (3). The 5-year survival rate for gastric cancer is $<20 \%$ (4). Angiogenesis is the formation of novel blood vessels from existing vessels and is required for the growth of solid tumors (5). Angiogenesis occurs at various stages during the malignant progression of the tumor and is a key step in tumor invasion and metastasis $(6,7)$. Notably, angiogenesis has been found to closely correlate with prognosis and hematogenous metastasis of gastric cancer (8). A balance between pro-angiogenic and anti-angiogenic factors in the local environment is important for the development of angiogenesis (5-7,9-11). Numerous pro-angiogenic factors, including factors that act directly and indirectly, are involved in the complex regulation of angiogenesis $(5-7,9,12,13)$.

Interleukin (IL)- 8 is a pro-inflammatory chemokine that belongs to the CXC subfamily and has been revealed to function as a significant regulatory factor within the tumor microenvironment (14). IL-8 is likely to be produced by a variety of human cancer cells, including gastric cancer cells (15). As a directly acting angiogenic factor, IL-8 promotes angiogenic responses in in vivo models $(14,16,17)$, and is markedly associated with tumor angiogenesis, including hepatocellular carcinoma $(18,19)$, cervical cancer (20), malignant melanoma (21) and nasopharyngeal carcinoma (22). However, the role of IL-8 in the activation of angiogenesis in gastric cancer remains unclear. Vascular endothelial growth factor (VEGF)-A interacts with VEGF receptor (VEGFR)-1 and VEGFR-2. As a key mediator of blood vessel growth, VEGF-A has been demonstrated to be a critical regulatory protein during angiogenesis and pathological neovascularization $(7,23,24)$. 
The aim of the present study was to investigate the role of IL-8 in the process of angiogenesis in gastric cancer. The present study evaluated the effects of IL-8 in angiogenesis and additionally investigated the expression of selected angiogenesis markers, consisting of VEGF-A, VEGFR-1 and VEGFR-2, using a co-culture model of human gastric cancer SGC-7901 cells and human umbilical vein endothelial cells (HUVECs).

\section{Materials and methods}

Cell culture. Human gastric cancer SGC-7901 cells and HUVECs were obtained from the cell bank of the Chinese Academy of Sciences (Beijing, China). All cells were propagated in endothelial cell medium (ECM; ScienCell, Carlsbad, CA, USA) and supplemented with $5 \%$ fetal bovine serum (FBS; Zhejiang Tianhang Biotechnology Co., Ltd., Hangzhou, Zhejiang, China), $1 \%$ endothelial cell growth supplement (ScienCell), $1 \%$ penicillin and streptomycin (Biological Industries, Beit Haemek, Israel) and 1\% L-glutamine (Biological Industries) for all experiments, with the exception of the tube formation assay. For the tube formation assay, SGC-7901 cells and HUVECs were propagated in Gibco Dulbecco's modified Eagle's medium (DMEM; Thermo Fisher Scientific, Inc., Waltham, MA, USA) and supplemented with 10\% FBS, $1 \%$ L-glutamine, $1 \%$ penicillin and streptomycin and $1 \%$ L-glutamine. All cells were maintained at $37^{\circ} \mathrm{C}$ in a humidified chamber containing $5 \% \mathrm{CO}_{2}$.

Co-culture model, cell grouping and IL-8 treatment. SGC-7901 cells were seeded in 24 -well plates $\left(5.5 \times 10^{4}\right.$ cells/well) and cultured for $24 \mathrm{~h}$ with predetermined concentrations of IL-8 stock solution (Sigma-Aldrich, St. Louis, MO, USA). Subsequently, the SGC-7901 cell culture media was collected and added to HUVECs for additional incubation. In total, 6 groups were established according to various specificities, as follows: Control group, ECM/DMEM without SGC7901 cell culture medium; $0.0 \mathrm{ng} / \mathrm{ml}$ IL-8 with SGC-7901 cell culture medium; $0.2 \mathrm{ng} / \mathrm{ml} \mathrm{IL-8} \mathrm{with} \mathrm{SGC-7901} \mathrm{cell} \mathrm{culture} \mathrm{medium;}$ $0.5 \mathrm{ng} / \mathrm{ml} \mathrm{IL-8} \mathrm{with} \mathrm{SGC-7901} \mathrm{cell} \mathrm{culture} \mathrm{medium;} 0.8 \mathrm{ng} / \mathrm{ml}$ IL-8 with SGC-7901 cell culture medium; and $1.0 \mathrm{ng} / \mathrm{ml} \mathrm{IL-8}$ with SGC-7901 cell culture medium.

Transwell chamber-induced migration assay. HUVEC cell migration was evaluated using Corning ${ }^{\circledR}$ Costar $^{\circledR}$ Transwell chambers (Corning Life Sciences, Tewksbury, MA, USA), according to the manufacturer's protocol. Briefly, HUVECs $\left(4 \times 10^{4}\right.$ cells) were seeded in the top chamber of the Transwell plate, while $600 \mu \mathrm{l}$ cell culture medium and various concentrations of IL-8 were placed in the lower chamber. Subsequent to $12 \mathrm{~h}$ incubation, the cells remaining on the upper surface of the polycarbonate membrane (non-migrated cells) were removed with blunt-ended cotton swabs. The cells that had attached to the opposite side of the membrane (migrated cells) were fixed with 4\% paraformaldehyde (Santa Cruz Biotechnology, Inc., Dallas, TX, USA) for $15 \mathrm{~min}$ and stained for $20 \mathrm{~min}$ using a crystal violet cell colony staining kit (Shanghai Sunred Biological Technology Co., Ltd, Shanghai, China). Following washing 3 times with PBS, images of the cells on the membrane were captured using an Olympus ${ }^{\circledR}$ CK40-F200 inverted microscope (Olympus, Tokyo, Japan). The results were expressed as the mean number of cells in 4 randomly selected microscopic fields at x10 magnification.

Matrigel tube formation assay. The formation of HUVECs into capillary-like structures was assessed using Matrigel (BD Biosciences, San Jose, CA, USA) in a tube formation assay. Briefly, Matrigel was thawed overnight, and the pipette and 96 -well plates were pre-chilled for $30 \mathrm{~min}$ at $4^{\circ} \mathrm{C}$. The Matrigel was added to each well of a $96-$ well plate $(80 \mu \mathrm{l} /$ well). All plates were maintained at $4^{\circ} \mathrm{C}$ for $30 \mathrm{~min}$ and $37^{\circ} \mathrm{C}$ for $30 \mathrm{~min}$, allowing the gel to polymerize. Subsequently, HUVECs were seeded on the Matrigel ( $1 \times 10^{4}$ cells/well) with $20 \mu 1$ DMEM and various concentrations of IL-8. Following additional 8, 12 and $16 \mathrm{~h}$ incubations, the formation of capillary-like structures was observed using a Zeiss laser confocal scanning microscope (model no., LSM710; Carl Zeiss AG, Oberkochen, Germany) at x40 magnification. The tube length was analyzed by the AxioVision Rel software, version 4.8 (Carl Zeiss AG). The results were expressed as the mean length of 4 randomly selected tubes.

Immunofluorescence staining. HUVECs were seeded onto coverslips on 24 -well plates $\left(5 \times 10^{4}\right.$ cells/well) and cultured with various concentrations of IL- 8 for $24 \mathrm{~h}$. Subsequently, the cells were fixed in $4 \%$ paraformaldehyde for $15 \mathrm{~min}$, permeabilized with $0.5 \%$ Triton-100 (Shanghai Sangong Pharmaceutical Co., Ltd., Shanghai, China) for $10 \mathrm{~min}$, incubated in $4 \%$ bovine serum albumin (Wisent Inc., St Bruno, QC, Canada), and cultured with rabbit anti-human VEGF-A (cat. no. 1909-1; dilution, 1:300; Epitomics, Burlingame, CA, USA) and VEGFR-1 monoclonal antibodies (cat. no. 1303-1; dilution, 1:300; Epitomics) and the rabbit anti-human VEGFR-2 polyclonal antibody (cat. no. ab39256; dilution, 1:150; Abcam, Cambridge, MA, USA), at $4^{\circ} \mathrm{C}$ overnight. Goat anti-rabbit Cy3-conjugated Affinipure immunoglobulin (Ig)G (heavy and light chains) antibody (cat. no. 10285-1-AP; dilution, 1:1,000; Wuhan Sanying Biotechnology, Wuhan, Hubei, China) was used as a secondary antibody, and was incubated with the primary antibodies for an additional $1 \mathrm{~h}$. The cell nuclei were then labeled with 4',6-diamidino-2-phenylindole. The coverslips were mounted on a glass slide and visualized under a Zeiss laser confocal scanning microscope.

Western blot analysis. HUVECs were seeded on 6-well plates ( $2 \times 10^{5}$ cells/well) and cultured for $24 \mathrm{~h}$ with various concentrations of IL-8. Subsequently, the cells were lysed using $150 \mu \mathrm{l}$ cell lysate buffer (Beyotime Institute of Biotechnology, Shanghai, China). Proteins in the total cell lysate were separated by SDS-PAGE (10\% separation gel; $5 \%$ spacer gel; Beyotime Institute of Biotechnology) and electrotransferred to polyvinylidene difluoride film (Bio-Rad, Laboratories, Inc., Hercules, CA, USA). Blotted films were placed in Tris-buffered saline with Tween (TBST; Santa Cruz Biotechnology, Inc.) for $1 \mathrm{~h}$ at room temperature. Rabbit anti-human VEGF-A (dilution, 1:250) and VEGFR-1 monoclonal antibodies (dilution, 1:250), rabbit anti-human VEGFR-2 polyclonal antibody (dilution, 1:250) and mouse anti-human glyceraldehyde 3-phosphate dehydrogenase (GAPDH) monoclonal antibody (cat. no. KM9002; dilution, 1:3,000; Tianjin Sungene Biotech Co., Ltd., Tianjin, China) were used to probe the blotted films overnight at $4^{\circ} \mathrm{C}$. Following a thorough wash with TBST, the blots were incubated 
Table I. Primer sequences used for quantitative polymerase chain reaction.

\begin{tabular}{ll}
\hline mRNA & \multicolumn{1}{c}{ Primer sequence (5'-3') } \\
\hline GAPDH & \\
Forward & PGGTGTGAACCATGAGAAGTATG \\
Reverse & GATGGCATGGACTGTGGTCAT \\
VEGF-A & \\
Forward & CTGCCATCCAATCGAGACCC \\
Reverse & TGCATTCACATTTGTTGTGCTG \\
VEGFR-1 & \\
Forward & AAGGCACCCAGCACATCAT \\
Reverse & ACCATTTCAGGCAAAGACCAT \\
VEGFR-2 & \\
Forward & CGATTATGGAAGTGAGTGAAAGAG \\
Reverse & CTGCCAATACCAGTGGATGTG \\
\hline
\end{tabular}

mRNA, messenger RNA; GAPDH, glyceraldehyde 3-phosphate dehydrogenase; VEGF, vascular endothelial growth factor; VEGFR, vascular endothelial growth factor receptor.

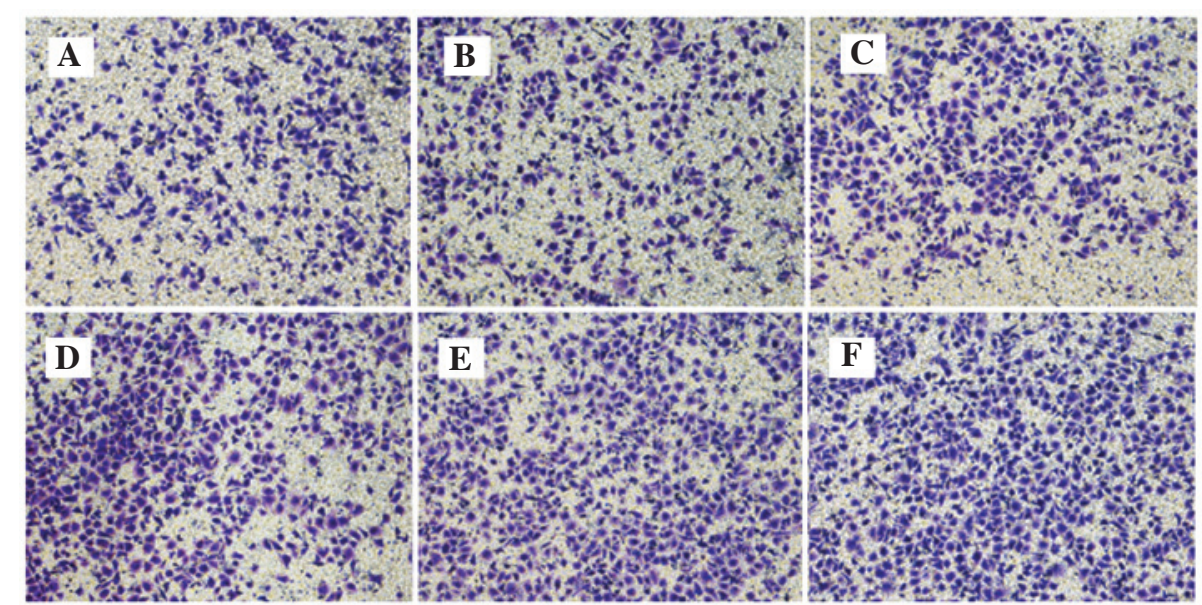

Figure 1. Migrated HUVECs observed using an inverted microscope at x10 magnification. (A) Control group, and following the addition of (B) 0.0 , (C) 0.2 , (D) 0.5 , (E) 0.8 and (F) $1.0 \mathrm{ng} / \mathrm{ml}$ IL-8. The cells were incubated for $12 \mathrm{~h}$. The pure SGC-7901 cell culture medium $(0.0 \mathrm{ng} / \mathrm{ml}$ group) exerted no significant effect on HUVEC migration compared with the control group. IL-8 at concentrations of $0.5,0.8$ and $1.0 \mathrm{ng} / \mathrm{ml}$ significantly promoted HUVEC migration, compared with no treatment, but not in a dose-dependent manner. HUVEC, human umbilical vein endothelial cells; IL-8, interleukin-8.

with goat anti-rabbit IgG-hydrogen peroxide (HRP) secondary antibody (dilution, 1:1,000; Santa Cruz Biotechnology, Inc.) or goat anti-mouse IgG-HRP secondary antibody (dilution, 1:3,000; Tianjin Sungene Biotech Co., Ltd.) for $1 \mathrm{~h}$ at room temperature. The blots were visualized using an enhanced chemiluminescence method, and were exposed to plain X-ray film in a darkroom. Grayscale reconstruction was performed by Image $\mathbf{J}$ software version 1.48 (National Institutes of Health, Bethesda, MD, USA; available from http://rsb.info.nih.gov./ij/), and the expression rate of the 3 proteins (VEGF-A, VEGFR-1 and VEGFR-2) relative to GAPDH protein expression (internal control) was calculated. All experiments were repeated 3 times.

Reverse transcription-quantitative polymerase chain reaction (RT-qPCR) analysis. HUVECs were seeded on a 12-well plate $\left(1 \times 10^{5}\right.$ cells/well $)$ and incubated with various concentrations of IL-8 for 24 h. Total RNA of the HUVECs was extracted using
TRIzol reagent (Takara Bio, Inc., Otsu, Shiga, Japan), according to the manufacturer's protocol. RT-qPCR was performed with SYBR ${ }^{\circledR}$ Green PCR mix in a Bio-Rad iQ5 PCR system (Bio-Rad Laboratories, Inc.). Each sample was analyzed 3 times. The PCR cycling conditions were as follows: 1 cycle at $95^{\circ} \mathrm{C}$ for $2 \mathrm{~min}$; 1 cycle at $95^{\circ} \mathrm{C}$ for $15 \mathrm{sec} ; 1$ cycle at $60^{\circ} \mathrm{C}$ for $20 \mathrm{sec} ; 1$ cycle at $72^{\circ} \mathrm{C}$ for $20 \mathrm{sec}$; and 40 cycles at $72^{\circ} \mathrm{C}$ for $30 \mathrm{sec}$. The PCR primers used for amplification are revealed in Table I. Based on the $2^{-\Delta \Delta \mathrm{Cq}}$ value (25), GAPDH mRNA was co-amplified to serve as an internal control, and the relative levels of VEGF-A, VEGFR-1 and VEGFR-2 mRNA expression were calculated.

Statistical analysis. Statistical analysis was performed using SPSS version 13.0 software (SPSS, Inc., Chicago, IL, USA). All data were presented as the mean \pm standard deviation. Analysis of variance (ANOVA) of repeated measurement data was used to assess tube formation. One-way ANOVA was used 
Table II. Effect of various concentrations of IL-8 on human umbilical vein endothelial cells migration and tube formation.

\begin{tabular}{lcccc}
\hline & & \multicolumn{2}{c}{ Tube length, $\mu \mathrm{m}$} \\
\cline { 3 - 5 } Group, ng/ml IL-8 & Migrated cells, $\mathrm{n}$ & $8 \mathrm{~h}$ & $12 \mathrm{~h}$ & $148.13 \pm 23.52$ \\
\hline Control & $420 \pm 38$ & $115.01 \pm 29.52$ & $142.78 \pm 27.35$ & $206.19 \pm 15.74$ \\
0.0 & $490 \pm 35$ & $125.51 \pm 28.36$ & $157.18 \pm 23.13$ & $240.51 \pm 28.25$ \\
0.2 & $603 \pm 71^{\mathrm{a}}$ & $123.96 \pm 20.01$ & $173.65 \pm 23.54$ & $249.03 \pm 17.33$ \\
0.5 & $696 \pm 90^{\mathrm{ab}}$ & $130.31 \pm 31.74$ & $174.15 \pm 8.08$ & $287.25 \pm 37.69$ \\
0.8 & $756 \pm 125^{\mathrm{abc}}$ & $132.17 \pm 27.30$ & $183.15 \pm 23.22$ & $335.86 \pm 34.46$ \\
1.0 & $792 \pm 71^{\mathrm{abd}}$ & $134.82 \pm 28.48$ & & \\
\hline
\end{tabular}

The data are expressed as the mean \pm standard deviation. ${ }^{a} \mathrm{P}<0.01$ vs. control group; ${ }^{b} \mathrm{P}<0.01 \mathrm{vs} .0 .0 \mathrm{ng} / \mathrm{ml} ;{ }^{c} \mathrm{P}<0.05$, ${ }^{\mathrm{d}} \mathrm{P}<0.01 \mathrm{vs}$. $0.2 \mathrm{ng} / \mathrm{ml}$. IL-8, interleukin-8.
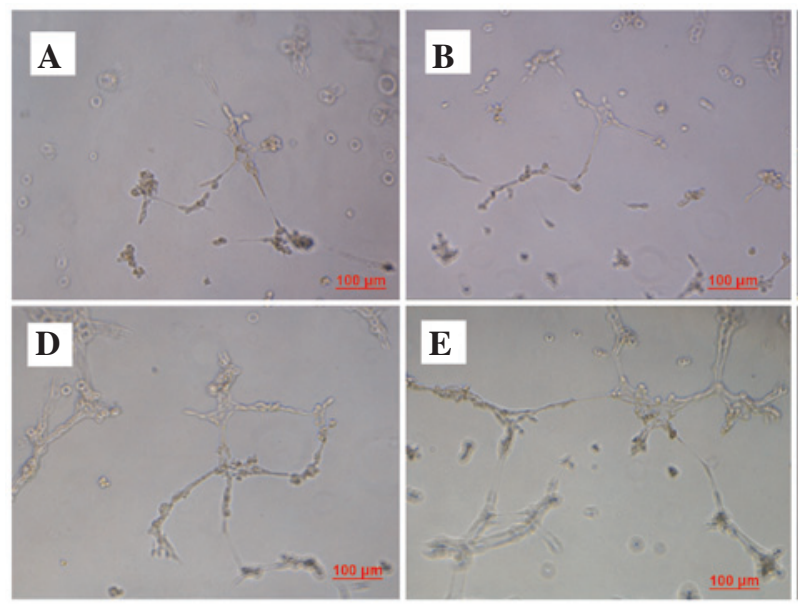

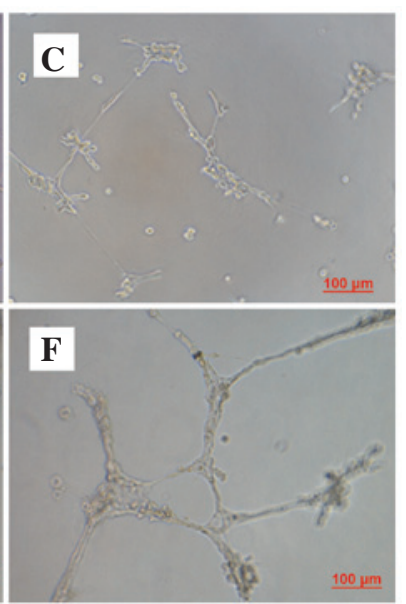

Figure 2. HUVEC tube formation observed assessed using a laser confocal scanning microscope at $\mathrm{x} 40$ magnification. (A) Control group, and following the addition of (B) 0.0, (C) 0.2, (D) 0.5, (E) 0.8 and (F) $1.0 \mathrm{ng} / \mathrm{ml} \mathrm{IL-8}$. The HUVECs were incubated for $16 \mathrm{~h}$. The pure SGC-7901 cell culture medium (0.0 ng/ml group) exerted no significant effect on HUVEC tube formation compared with the control group. IL- 8 at concentrations of $0.5,0.8$ and $1.0 \mathrm{ng} / \mathrm{ml}$ significantly promoted HUVEC tube formation, compared with no treatment. HUVEC, human umbilical vein endothelial cells; IL-8, interleukin-8.

to assess migration, and protein and mRNA expression levels. The Fisher's least significant difference method was used to analyze multiple post-hoc comparisons. $\mathrm{P}<0.05$ was considered to indicate a statistically significant difference.

\section{Results}

IL-8 promoted HUVEC migration. As demonstrated by Table II and Fig. 1, the addition of IL- 8 significantly affected HUVEC migration compared with the control cells under experimental conditions $(\mathrm{P}<0.001)$. The pure SGC-7901 cell culture medium ( $0.0 \mathrm{ng} / \mathrm{ml}$ group) exerted no significant effect on HUVEC migration $(\mathrm{P}=0.249)$. IL- 8 at concentrations of $0.5,0.8$ and $1.0 \mathrm{ng} / \mathrm{ml}$ significantly promoted HUVEC migration $(\mathrm{P}=0.005, \mathrm{P}=0.001$ and $\mathrm{P}<0.001$, respectively). However, no significant differences in HUVEC migration was observed between the various concentrations administered $(\mathrm{P}>0.05)$.

IL-8 promoted HUVEC tube formation. Tube formation increased gradually subsequent to $8 \mathrm{~h}$ of treatment. The tube lengths between the various time points were significantly different $(\mathrm{P}<0.001)$. As demonstrated by Table II and Fig. 2, the administration of IL- 8 significantly affected HUVEC tube formation $(\mathrm{P}<0.001)$. The pure SGC-7901 cell culture medium exerted no significant effect on HUVEC migration compared with the control cells $(\mathrm{P}=0.517)$. IL- 8 at concentrations of $0.5,0.8$ and $1.0 \mathrm{ng} / \mathrm{ml}$ significantly promoted HUVEC tube formation, compared with the $0.0 \mathrm{ng} / \mathrm{ml}$ group $(\mathrm{P}=0.039$, $\mathrm{P}=0.003$ and $\mathrm{P}<0.001$, respectively). Furthermore, the tube length of the $1.0 \mathrm{ng} / \mathrm{ml}$ group was increased compared with the tube length of the $0.2 \mathrm{ng} / \mathrm{ml}(\mathrm{P}=0.001)$ and $0.5 \mathrm{ng} / \mathrm{ml}$ $(\mathrm{P}=0.011)$ groups, but not the $0.8 \mathrm{ng} / \mathrm{ml}$ group $(\mathrm{P}=0.105)$.

\section{IL-8 promoted VEGF-A, VEGFR-1 and VEGFR-2 protein} expression levels in HUVECs. As demonstrated by Table III, and Figs. 3 and 4, the addition of IL-8 significantly altered the VEGF-A, VEGFR-1 and VEGFR-2 protein expression levels compared with the control cells $(\mathrm{P}<0.001, \mathrm{P}=0.009$ and $\mathrm{P}<0.001$, respectively). The pure SGC-7901 cell culture medium significantly upregulated the expression of VEGF-A protein $(\mathrm{P}=0.019)$. IL-8 at concentrations $>0.2 \mathrm{ng} / \mathrm{ml}$ markedly increased VEGF-A protein levels compared with the $0.0 \mathrm{ng} / \mathrm{ml}$ group $(\mathrm{P}<0.001)$. The pure SGC-7901 cell culture medium exerted no significant effect on VEGFR-1 
Table III. Effect of various concentrations of IL-8 on VEGF-A, VEGFR-1 and VEGFR-2 protein expression levels in human umbilical vein endothelial cells.

\begin{tabular}{llll}
\hline Group, ng/ml IL-8 & VEGF-A & VEGFR-1 & VEGFR-2 \\
\hline Control & $1.00 \pm 0.00$ & $1.00 \pm 0.00$ & $1.00 \pm 0.00$ \\
0.0 & $1.17 \pm 0.05^{\mathrm{a}}$ & $1.00 \pm 0.01$ & $0.69 \pm 0.02^{\mathrm{b}}$ \\
0.2 & $1.70 \pm 0.00^{\mathrm{bd}}$ & $1.00 \pm 0.04$ & $0.74 \pm 0.04^{\mathrm{bc}}$ \\
0.5 & $1.75 \pm 0.03^{\mathrm{bd}}$ & $1.03 \pm 0.03$ & $0.85 \pm 0.02^{\mathrm{bdf}}$ \\
0.8 & $2.10 \pm 0.13^{\mathrm{bdfg}}$ & $1.10 \pm 0.03^{\text {ace }}$ & $0.86 \pm 0.03^{\mathrm{bdfg}}$ \\
1.0 & $2.78 \pm 0.12^{\text {bdfgh }}$ & $1.17 \pm 0.12^{\text {bdfg }}$ & $1.00 \pm 0.03^{\text {dfh }}$ \\
\hline
\end{tabular}

The data are expressed as the mean \pm standard deviation. ${ }^{\mathrm{a}} \mathrm{P}<0.05,{ }^{\mathrm{b}} \mathrm{P}<0.01 \mathrm{vs}$. control group; ${ }^{\mathrm{c}} \mathrm{P}<0.05,{ }^{\mathrm{d}} \mathrm{P}<0.01 \mathrm{vs} .0 .0 \mathrm{ng} / \mathrm{ml}$; ${ }^{\mathrm{e}} \mathrm{P}<0.05$, ${ }^{\mathrm{f}} \mathrm{P}<0.01 \mathrm{vs} .0 .2 \mathrm{ng} / \mathrm{ml}$; ${ }^{\mathrm{P}}<0.01 \mathrm{vs} .0 .5 \mathrm{ng} / \mathrm{ml}$; ${ }^{\mathrm{P}} \mathrm{P}<0.01 \mathrm{vs} .0 .8 \mathrm{ng} / \mathrm{ml}$. IL-8, interleukin-8; VEGF, vascular endothelial growth factor; VEGFR, VEGF receptor.

Table IV. Effect of various concentrations of IL-8 on VEGF-A, VEGFR-1 and VEGFR-2 mRNA expression levels in human umbilical vein endothelial cells.

\begin{tabular}{llll}
\hline & & mRNA & \\
\cline { 2 - 4 } Group, ng/ml IL-8 & VEGF-A & VEGFR-1 & VEGFR-2 \\
\hline Control & $1.01 \pm 0.15$ & $1.00 \pm 0.09$ & $1.00 \pm 0.04$ \\
0.0 & $1.12 \pm 0.06$ & $0.50 \pm 0.09^{\mathrm{b}}$ & $0.83 \pm 0.01$ \\
0.2 & $1.33 \pm 0.02^{\mathrm{a}}$ & $0.64 \pm 0.00^{\mathrm{b}}$ & $1.73 \pm 0.09^{\mathrm{ad}}$ \\
0.5 & $1.38 \pm 0.04^{\mathrm{bc}}$ & $0.73 \pm 0.10^{\mathrm{ac}}$ & $1.63 \pm 0.28^{\text {ad }}$ \\
0.8 & $1.61 \pm 0.25^{\mathrm{bde}}$ & $1.61 \pm 0.11^{\mathrm{bdfg}}$ & $3.06 \pm 0.49^{\mathrm{bdfg}}$ \\
1.0 & $1.77 \pm 0.20^{\mathrm{bdfg}}$ & $1.56 \pm 0.24^{\mathrm{bdfg}}$ & $2.90 \pm 0.42^{\mathrm{bdfg}}$ \\
\hline
\end{tabular}

The data is expressed as the mean \pm standard deviation. ${ }^{\mathrm{a}} \mathrm{P}<0.05,{ }^{\mathrm{b}} \mathrm{P}<0.01 \mathrm{vs}$. control group; ${ }^{\mathrm{c}} \mathrm{P}<0.05,{ }^{\mathrm{d}} \mathrm{P}<0.01 \mathrm{vs} .0 .0 \mathrm{ng} / \mathrm{ml} ;{ }^{\mathrm{e}} \mathrm{P}<0.05$, ${ }^{\mathrm{f}} \mathrm{P}<0.01 \mathrm{vs} .0 .2 \mathrm{ng} / \mathrm{ml}$; ${ }^{\mathrm{g}} \mathrm{P}<0.01 \mathrm{vs} .0 .5 \mathrm{ng} / \mathrm{ml}$. IL-8, interleukin-8; VEGF, vascular endothelial growth factor; VEGFR, VEGF receptor; mRNA, messenger RNA.

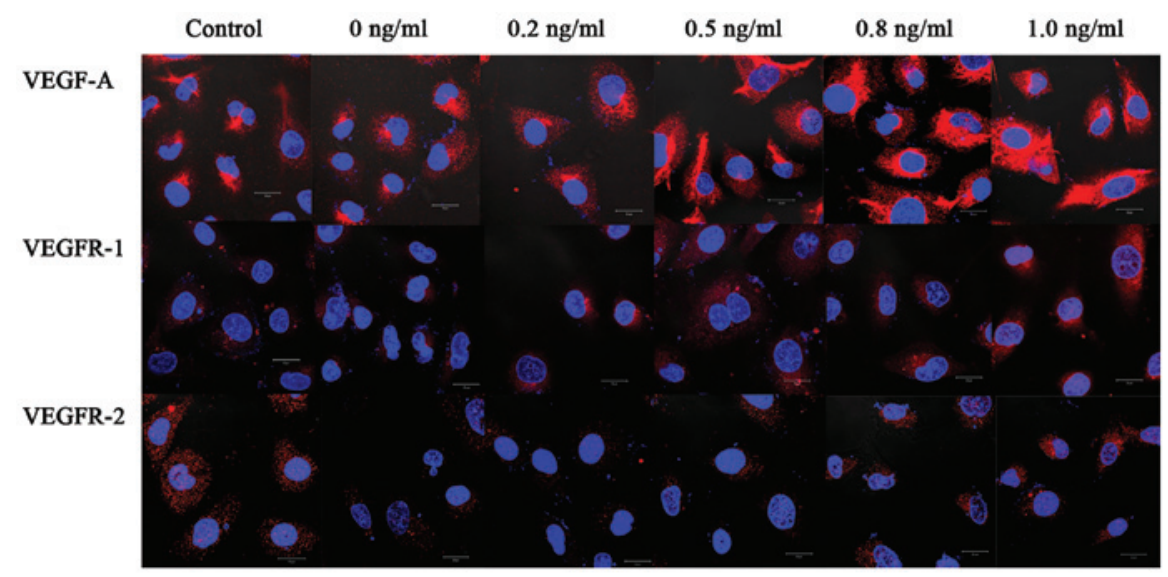

Figure 3. Effect of various concentrations of IL-8 on VEGF-A, VEGFR-1 and VEGFR-2 protein expression levels in HUVECs assessed using immunofluorescence staining. Cell nuclei were detected with 4',6-diamidino-2-phenylindole (blue) staining. The VEGF-A, VEGFR-1 and VEGFR-2 proteins were counterstained with goat anti-rabbit Cy3-conjugated Affinipure immunoglobulin G antibody (red). IL-8, interleukin-8; HUVECs, human umbilical vein endothelial cells; VEGF, vascular endothelial growth factor; VEGFR, vascular endothelial growth factor receptor.

protein expression $(\mathrm{P}=0.9999)$. IL-8 at concentrations of 0.8 and $1.0 \mathrm{ng} / \mathrm{ml}$ enhanced VEGFR-1 protein expression $(\mathrm{P}=0.037$ and $\mathrm{P}=0.002$, respectively). Notably, the pure
SGC-7901 cell culture medium downregulated the expression of the VEGFR-2 protein $(\mathrm{P}<0.001)$. However, IL-8 at concentrations $>0.2 \mathrm{ng} / \mathrm{ml}$ markedly increased VEGFR-2 


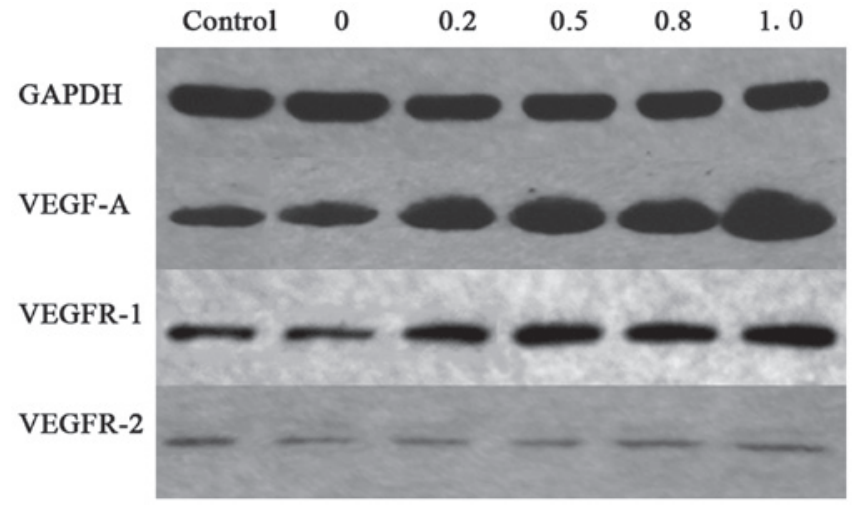

Figure 4. Effect of various concentrations of IL-8 on the protein expression levels of VEGF-A, VEGFR-1 and VEGFR-2 in HUVECs, assessed using western blot analysis. The pure SGC-7901 cell culture medium significantly upregulated the expression of VEGF-A protein, but downregulated the expression of VEGFR-2 protein, and exerted no significant effect on the expression of VEGFR-1 protein. IL-8 at concentrations of 0.2, 0.5, 0.8 and $1.0 \mathrm{ng} / \mathrm{ml}$ increased VEGF-A and VEGFR-2 protein levels compared with the $0 \mathrm{ng} / \mathrm{ml}$ group. IL- 8 at concentrations of 0.8 and $1.0 \mathrm{ng} / \mathrm{ml}$ enhanced VEGFR-1 protein expression. IL-8, interleukin-8; VEGF, vascular endothelial growth factor; VEGFR, vascular endothelial growth factor receptor; HUVEC, human umbilical vein endothelial cells; GAPDH, glyceraldehyde 3-phosphate dehydrogenase.

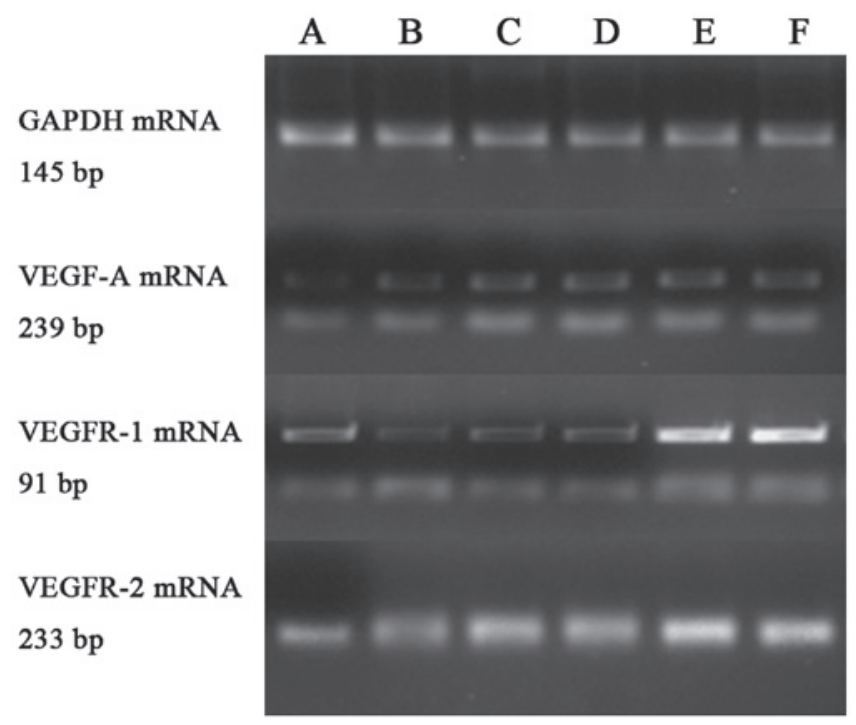

Figure 5. Effect of various concentrations of IL-8 on VEGF-A, VEGFR-1 and VEGFR-2 mRNA expression levels in human umbilical vein endothelia cells using reverse transcription-quantitative polymerase chain reaction. Lanes A-F: Control and 0.0, 0.2, 0.5, 0.8 and $1.0 \mathrm{ng} / \mathrm{ml} \mathrm{IL-8} \mathrm{groups,} \mathrm{respec-}$ tively. The pure SGC-7901 cell culture medium did not affect VEGF-A and VEGFR-2 mRNA expression, but downregulated VEGFR-1 mRNA expression. IL- 8 at concentrations $>0.5 \mathrm{ng} / \mathrm{ml}$ upregulated VEGF-A and VEGFRmRNA levels. IL- 8 at concentrations $>0.2 \mathrm{ng} / \mathrm{ml}$ upregulated VEGFR-2 mRNA levels. IL-8, interleukin-8; VEGF, vascular endothelial growth factor; VEGFR, vascular endothelial growth factor receptor; GAPDH, glyceraldehyde 3-phosphate dehydrogenase.

protein levels compared with the $0.0 \mathrm{ng} / \mathrm{ml}$ group $(0.2 \mathrm{ng} / \mathrm{ml}$ vs. $0.0 \mathrm{ng} / \mathrm{ml}, \mathrm{P}=0.034 ; 0.5 \mathrm{ng} / \mathrm{ml}$ vs. $0.0 \mathrm{ng} / \mathrm{ml}, \mathrm{P}<0.001$; $0.8 \mathrm{ng} / \mathrm{ml}$ vs. $0.0 \mathrm{ng} / \mathrm{ml}, \mathrm{P}<0.001 ; 1.0 \mathrm{ng} / \mathrm{ml}$ vs. $0.0 \mathrm{ng} / \mathrm{ml}$, $\mathrm{P}<0.001)$. The VEGFR-2 protein level following the addition of $1.0 \mathrm{ng} / \mathrm{ml}$ of IL- 8 revealed no significant difference compared with the control group $(\mathrm{P}=0.876)$.
IL-8 promoted VEGF-A, VEGFR-1 and VEGFR-2 mRNA expression levels in HUVECs. As demonstrated by Table IV and Fig. 5, the administration of IL-8 significantly affected the VEGF-A, VEGFR-1 and VEGFR-2 mRNA expression levels compared with the control cells $(\mathrm{P}<0.001)$. The pure SGC-7901 cell culture medium exerted no significant effect on VEGF-A and VEGFR-2 mRNA expression ( $\mathrm{P}=0.376$ and $\mathrm{P}=0.487$, respectively), but downregulated the expression of VEGFR-1 mRNA $(\mathrm{P}<0.001)$. IL-8 at concentrations of 0.5 , 0.8 and $1.0 \mathrm{ng} / \mathrm{ml}$ markedly increased the mRNA expression of VEGF-A $(\mathrm{P}=0.046, \mathrm{P}=0.001$ and $\mathrm{P}<0.001$, respectively) and VEGFR-1 $(\mathrm{P}=0.042, \mathrm{P}<0.001$ and $\mathrm{P}<0.001$, respectively) compared with the $0.0 \mathrm{ng} / \mathrm{ml}$ group. IL- 8 at concentrations $>0.2 \mathrm{ng} / \mathrm{ml}$ markedly increased VEGFR-2 mRNA levels compared with the $0.0 \mathrm{ng} / \mathrm{ml}$ group $(0.2 \mathrm{ng} / \mathrm{ml}, \mathrm{P}=0.003$; $0.5 \mathrm{ng} / \mathrm{ml}, \mathrm{P}=0.005 ; 0.8 \mathrm{ng} / \mathrm{ml}, \mathrm{P}<0.001$; and $1.0 \mathrm{ng} / \mathrm{ml}$, $\mathrm{P}<0.001)$.

\section{Discussion}

Angiogenesis is a complex process involving multiple pro- and anti-angiogenic factors. Currently, angiogenesis is acknowledged as a key and validated cancer therapeutic target due to its pivotal role in the progression and metastasis of malignancies $(26,27)$. Worldwide, gastric cancer is one of the leading causes of cancer-associated mortality (2). Tumor angiogenesis is closely associated with the prognosis and hematogenous metastasis of gastric cancer (8). IL-8 is a chemokine and a pro-inflammatory mediator (14). The present study evaluated the role of IL- 8 in the angiogenesis of gastric cancer. The present data demonstrated that IL-8 may be a potent promoter of angiogenesis in gastric cancer. This result directly supports the hypothesis that IL- 8 may be a promising therapeutic target for gastric cancer.

IL- 8 is a member of the CXC chemokine family, and is released through the nuclear factor $-\kappa \mathrm{B}(\mathrm{NF}-\kappa \mathrm{B})$ signaling pathway. Increased IL- 8 expression levels have been detected in numerous types of human cancer, including human melanoma (28), squamous cell carcinoma (29) and cervical (30), ovarian (31), non-small cell lung (32), colon (33) and gastric cancers (15). Previous evidence has revealed that IL-8 is markedly associated with the development and metastasis of gastric cancer via autocrine and paracrine mechanisms (34). In vivo, IL-8 is important in the depth of invasion and venous and lymphatic invasion of tumors, and may be an independent prognostic factor in human gastric carcinoma (35). In vitro, the IL-8 level is significantly associated with the adhesion, migration, invasion and chemosensitivity of human gastric cancer cells $(36,37)$.

It is widely accepted that IL-8 acts as a pro-angiogenic mediator $(14,16,17)$. Due to its pro-angiogenic characteristics, IL-8 may be a key mediator in the angiogenesis and progression of various tumors. IL-8 has been revealed to be involved in seminal plasma-induced regulation of vascular function in cervical cancer (20), transition between liver cirrhosis and highly vascularized hepatocellular carcinoma (18), the malignant phenotype of hematological malignancies (38), Epstein-Barr virus latent membrane protein-1-induced angiogenesis in nasopharyngeal carcinoma through the $\mathrm{NF}-\kappa \mathrm{B}-$ binding site (22) and tumor growth and angiogenesis 
in melanoma via the secretion of tumor necrosis factor $\alpha$ and IL-1 $\alpha$ (21). A previous study has identified that gastric cancer cells secret various levels of IL-8 protein and, more notably, the level of IL-8 mRNA in the neoplasms is markedly associated with vascularization in vivo, suggesting that IL-8 may regulate neovascularization and the growth and spread of gastric cancer (39). However, the role of IL-8 in gastric cancer angiogenesis remains unclear, and few studies have investigated its role in gastric cancer angiogenesis in vitro. The present data reveal that IL-8 significantly promotes HUVEC migration and tube formation, which were co-cultured with human gastric cancer SGC-7901 cells, therefore supporting the hypothesis that IL-8 promotes angiogenesis in gastric cancer.

VEGFs belong to a platelet-derived growth factor supergene family. It is widely accepted that these factors are important signaling proteins involved in lymphangiogenesis and angiogenesis (40). VEGF-A, the prototype VEGF ligand, which was originally isolated from tumor cells, is a key factor in angiogenesis and vascular permeability $(7,24)$. As a tumor angiogenesis factor, VEGF-A is crucial for the pathological angiogenesis of various cancers, including chronic lymphocytic leukemia (41), astrocytic tumors (42) and breast (43), non-small cell lung (44), colorectal (45) and gastric cancers (46). Therefore, VEGF-A is regarded as a marker for angiogenesis, and currently anti-VEGF therapy is widely used in clinical settings to treat various cancers (40). A previous study reported that IL-8 stimulates VEGF-A expression in endothelial cells (47); however, the interaction between IL- 8 and VEGF-A in gastric cancer remains unknown. The present study revealed that IL- 8 enhanced VEGF-A protein and mRNA expression in vitro, indicating that IL-8 may be a promoter of angiogenesis in gastric cancer.

The VEGF-VEGFR signaling system is important, not only in physiological angiogenesis from early embryonic to adult stages, but also in pathological angiogenesis, including in cancers (48-52). VEGF-A binds and activates the two tyrosine kinase (TK) receptors VEGFR-1 and VEGFR-2. VEGFR-2 $(200-230 \mathrm{kDa})$ is a key factor in vascular and hematopoietic development and activates almost all endothelial cell responses by binding to VEGF-A (53). VEGFR-2 is abundant in various types of cancer. Furthermore, the localization of VEGFR-2 expression is important in cancer pathogenesis (53), and VEGFR-2 exhibits strong TK activity towards pro-angiogenic signals (40). Therefore, VEGFR-2 is usually investigated as a key marker of angiogenesis in cancer (53-55). It has previously been reported that IL- 8 stimulates the autocrine activation of VEGFR-2 in endothelial cells by the activation of $\mathrm{NF}-\kappa \mathrm{B}$ through the caspase recruitment domain and membrane-associated guanylate kinase-like domain-containing protein/B-cell lymphoma-10/mucosa-associated lymphoid tissue lymphoma translocation-1 complex (47). IL-8 activates chemokine (C-X-C motif) receptor $1 / 2$ on endothelial cells, leading to VEGFR-2 transactivation, and this is required for IL-8-induced endothelial permeability $(56,57)$. However, there is little evidence concerning the association between IL- 8 and VEGFR-2 in gastric cancer. The present study demonstrated that IL-8 elevated VEGFR-2 protein and mRNA levels, supporting the hypothesis that IL-8 may be a pro-angiogenesis factor in gastric cancer.

VEGFR-1 (180 kDa) has an extremely high affinity for its ligand, VEGF; however, the kinase activity of VEGFR-1 is one-tenth lower compared to that of VEGFR-2 (40). The role of VEGFR-1 in the angiogenesis of cancer remains ambiguous and ambivalent. A previous study revealed that the mechanism of VEGF regulation of angiogenesis may be due to the enhanced proliferation of VEGFRs, particularly VEGFR-1 (54). However, an additional study identified that VEGFR-1 may negatively regulate angiogenesis under certain conditions, and VEGFR-1 is a suppressor of VEGFR-2 signaling (40). The current study demonstrated that IL-8 promoted VEGFR-1 protein and mRNA expression. Placental growth factor (PlGF) is an additional VEGF family member that also binds VEGFR-1 (58). PIGF has been revealed to stimulate angiogenesis and collateral growth in ischemic heart and limbs, with a comparable efficiency to VEGF (58). PIGF and VEGFR-1 have been hypothesized to be novel therapeutic targets for angiogenesis (58). The present study hypothesizes that the effect of IL-8 in enhancing the VEGFR-1 level, involved in the promotion of angiogenesis, may be due to IL-8-induced PlGF overexpression. The potential regulatory mechanisms of the interaction between IL-8 and VEGFR-1 require additional investigation.

In conclusion, the present data revealed that IL-8 significantly promotes HUVEC migration and tube formation, and increases the expression levels of the VEGF-A, VEGFR-1 and VEGFR-2 proteins and mRNA, suggesting that IL-8 may be a potent promoter of angiogenesis in gastric cancer.

\section{Acknowledgements}

The present studywas supported by grants fromthe 3-Year Action Plan Fund of Traditional Chinese Medicine, Shanghai City Health Administration (grant no's. ZYSNXD-CC-ZDYJ024 and ZY3-RCPY-3-1016) and the National Natural Science Foundation of China (grant no. 81573762).

\section{References}

1. Parkin DM, Bray F, Ferlay J and Pisani P: Global cancer statistics, 2002. CA Cancer J Clin 55: 74-108, 2005.

2. Ferlay J, Soerjomataram I, Ervik M, et al: GLOBOCAN 2012 v1.0, Cancer incidence and mortality worldwide, No. 11 http://globocan.iarc.fr/. Accessed August 08, 2014.

3. Suh YS and Yang HK: Screening and early detection of gastric cancer: East versus west. Surg Clin North Am 95: 1053-1066, 2015.

4. GASTRIC (Global Advanced/Adjuvant Stomach Tumor Research International Collaboration) Group; Paoletti X, Oba K, et al: Benefit of adjuvant chemotherapy for resectable gastric cancer: A meta-analysis. JAMA 303: 1729-1737, 2010.

5. Folkman J: Angiogenesis in cancer, vascular, rheumatoid and other disease. Nat Med 1: 27-31, 1995.

6. Carmeliet P and Jain RK: Principles and mechanisms of vessel normalization for cancer and other angiogenic diseases. Nat Rev Drug Discov 10: 417-427, 2011.

7. Carmeliet P and Jain RK: Angiogenesis in cancer and other diseases. Nature 407: 249-257, 2000.

8. Saito H and Tsujitani S: Angiogenesis, angiogenic factor expression and prognosis of gastric carcinoma. Anticancer Res 21 (6B): 4365-4372, 2001.

9. Folkman J: Angiogenesis: An organizing principle for drug discovery? Nat Rev Drug Discov 6: 273-286, 2007.

10. Patel-Hett S and D'Amore PA: Signal transduction in vasculogenesis and developmental angiogenesis. Int J Dev Biol 55: 353-363, 2011.

11. De Spiegelaere W, Casteleyn C, Van den Broeck W, et al: Intussusceptive angiogenesis: A biologically relevant form of angiogenesis. J Vasc Res 49: 390-404, 2012.

12. Koch S: Neuropilin signalling in angiogenesis. Biochem Soc Trans 40: 20-25, 2012. 
13. Tung JJ, Tattersall IW and Kitajewski J: Tips, stalks, tubes: Notch-mediated cell fate determination and mechanisms of tubulogenesis during angiogenesis. Cold Spring Harb Perspect Med 2: a006601, 2012.

14. Waugh DJ and Wilson C: The interleukin-8 pathway in cancer. Clin Cancer Res 14: 6735-6741, 2008.

15. Takagi A, Kamiya S, Koga Y, et al: Analysis of interleukin-8 secretion induced by Helicobacter pylori from the gastric epithelial cell line MKN45: A mechanism independent of the intensity of cytotoxicity. J Gastroenterol Hepatol 12: 368-372, 1997.

16. Koch AE, Polverini PJ, Kunkel SL, et al: Interleukin-8 as a macrophage-derived mediator of angiogenesis. Science 258 1798-1801, 1992.

17. Strieter RM, Kunkel SL, Elner VM, et al: Interleukin-8. A corneal factor that induces neovascularization. Am J Pathol 141: 1279-1284, 1992.

18. Nomura T, Morishita A, Jian G, et al: Expression of angiogenic factors in hepatocarcinogenesis: Identification by antibody arrays. Oncol Rep 30: 2476-2480, 2013.

19. Akiba J, Yano H, Ogasawara S, Higaki K and Kojiro M: Expression and function of interleukin-8 in human hepatocellular carcinoma. Int J Oncol 18: 257-264, 2001.

20. Sales KJ, Sutherland JR, Jabbour HN and Katz AA: Seminal plasma induces angiogenic chemokine expression in cervical cancer cells and regulates vascular function. Biochim Biophys Acta 1823: 1789-1795, 2012.

21. Torisu H, Ono M, Kiryu H, et al: Macrophage infiltration correlates with tumor stage and angiogenesis in human malignant melanoma: Possible involvement of TNFalpha and IL-1alpha. Int J Cancer 85: 182-188, 2000.

22. Yoshizaki T, Horikawa T, Qing-Chun R, et al: Induction of interleukin- 8 by Epstein-Barr virus latent membrane protein-1 and its correlation to angiogenesis in nasopharyngeal carcinoma. Clin Cancer Res 7: 1946-1951, 2001.

23. Ferrara $\mathrm{N}$ and Davis-Smyth T: The biology of vascular endothelial growth factor. Endocr Rev 18: 4-25, 1997.

24. Ferrara N: Vascular endothelial growth factor. Arterioscler Thromb Vasc Biol 29: 789-791, 2009.

25. Livak KJ and Schmittgen TD: Analysis of relative gene expression data using real-time quantitative PCR and the $2^{-\Delta \Delta C T}$ method. Methods 25: 402-408, 2001.

26. Meadows KL and Hurwitz HI: Anti-VEGF therapies in the clinic. Cold Spring Harb Perspect Med 2: a006577, 2012.

27. Friis T, Engel AM, Bendiksen CD, Larsen LS and Houen G: Influence of levamisole and other angiogenesis inhibitors on angiogenesis and endothelial cell morphology in vitro. Cancers (Basel) 5: 762-785, 2013.

28. Gabellini C, Trisciuoglio D, Desideri M, et al: Functional activity of CXCL8 receptors, CXCR1 and CXCR2, on human malignant melanoma progression. Eur J Cancer 45: 2618-2627, 2009.

29. Christofakis EP, Miyazaki H, Rubink DS and Yeudall WA: Roles of CXCL8 in squamous cell carcinoma proliferation and migration. Oral Oncol 44: 920-926, 2008.

30. Wu S, Shang H, Cui L, Zhang Z, Zhang Y,Li Y, Wu J,Li RK and Xie J: Targeted blockade of interleukin-8 abrogates its promotion of cervical cancer growth and metastasis. Mol Cell Biochem 375: 69-79, 2013.

31. Wang Y, Xu RC, Zhang XL, et al: Interleukin-8 secretion by ovarian cancer cells increases anchorage-independent growth, proliferation, angiogenic potential, adhesion and invasion. Cytokine 59: 145-155, 2012.

32. Luppi F, Longo AM, de Boer WI, Rabe KF and Hiemstra PS: Interleukin-8 stimulates cell proliferation in non-small cell lung cancer through epidermal growth factor receptor transactivation. Lung Cancer 56: 25-33, 2007.

33. Ning Y, Manegold PC, Hong YK, et al: Interleukin-8 is associated with proliferation, migration, angiogenesis and chemosensitivity in vitro and in vivo in colon cancer cell line models. Int J Cancer 128: 2038-2049, 2011.

34. Kitadai Y, Haruma K, Mukaida N, et al: Regulation of disease-progression genes in human gastric carcinoma cells by interleukin 8. Clin Cancer Res 6: 2735-2740, 2000.

35. Kido S, Kitadai Y, Hattori N, et al: Interleukin 8 and vascular endothelial growth factor - prognostic factors in human gastric carcinomas? Eur J Cancer 37: 1482-1487, 2001.

36. Ju D, Sun D, Xiu L, et al: Interleukin-8 is associated with adhesion, migration and invasion in human gastric cancer SCG-7901 cells. Med Oncol 29: 91-99, 2012.
37. Kuai WX, Wang Q, Yang XZ, et al: Interleukin-8 associates with adhesion, migration, invasion and chemosensitivity of human gastric cancer cells. World J Gastroenterol 18: 979-985, 2012.

38. Negaard HF, Iversen N, Bowitz-Lothe IM, et al: Increased bone marrow microvascular density in haematological malignancies is associated with differential regulation of angiogenic factors. Leukemia 23: 162-169, 2009.

39. Kitadai Y, Haruma K, Sumii K, et al: Expression of interleukin-8 correlates with vascularity in human gastric carcinomas. Am J Pathol 152: 93-100, 1998.

40. Shibuya M: Vascular endothelial growth factor and its receptor system: Physiological functions in angiogenesis and pathological roles in various diseases. J Biochem 153: 13-19, 2013.

41. Ayad MW and El Naggar AA: Angiogenic factor VEGF and its relationship with biological prognostic markers in chronic lymphocytic leukemia. Egypt J Immunol 17: 59-71, 2010.

42. Ido K, Nakagawa T, Sakuma T, et al: Expression of vascular endothelial growth factor-A and mRNA stability factor HuR in human astrocytic tumors. Neuropathology 28: 604-611, 2008.

43. Xu X, Wang B, Ye C, et al: Overexpression of macrophage migration inhibitory factor induces angiogenesis in human breast cancer. Cancer Lett 261: 147-157, 2008.

44. Giatromanolaki A, Koukourakis MI, Sivridis E, et al: Coexpression of MUC1 glycoprotein with multiple angiogenic factors in non-small cell lung cancer suggests coactivation of angiogenic and migration pathways. Clin Cancer Res 6: 1917-1921, 2000.

45. Rasheed S, McDonald PJ, Northover JM and Guenther T: Angiogenesis and hypoxic factors in colorectal cancer. Pathol Res Pract 204: 501-510, 2008.

46. He LF, Wang TT, Gao QY, et al: Stanniocalcin-1 promotes tumor angiogenesis through up-regulation of VEGF in gastric cancer cells. J Biomed Sci 18: 39, 2011.

47. Martin D, Galisteo R and Gutkind JS: CXCL8/IL8 stimulates vascular endothelial growth factor (VEGF) expression and the autocrine activation of VEGFR2 in endothelial cells by activating NFkappaB through the CBM (Carma3/Bcl10/Malt1) complex. J Biol Chem 284: 6038-6042, 2009.

48. Ferrara N and Kerbel RS: Angiogenesis as a therapeutic target. Nature 438: 967-974, 2005.

49. Shibuya M: Involvement of Flt-1 (VEGF receptor-1) in cancer and preeclampsia. Proc Jpn Acad, Ser B, Phys Biol Sci 87: 167-178, 2011.

50. Shibuya M and Claesson-Welsh L: Signal transduction by VEGF receptors in regulation of angiogenesis and lymphangiogenesis. Exp Cell Res 312: 549-560, 2006.

51. Alitalo K and Carmeliet P: Molecular mechanisms of lymphangiogenesis in health and disease. Cancer Cell 1: 219-227, 2002.

52. Jakobsson L, Bentley K and Gerhardt H: VEGFRs and Notch: A dynamic collaboration in vascular patterning. Biochem Soc Trans 37: 1233-1236, 2009 .

53. Kampen KR: The mechanisms that regulate the localization and overexpression of VEGF receptor-2 are promising therapeutic targets in cancer biology. Anticancer Drugs 23: 347-354, 2012.

54. Tas F, Duranyildiz D, Oguz H, et al: Circulating serum levels of angiogenic factors and vascular endothelial growth factor receptors 1 and 2 in melanoma patients. Melanoma Res 16: 405-411, 2006.

55. Hanrahan EO, Lin HY, Kim ES, et al: Distinct patterns of cytokine and angiogenic factor modulation and markers of benefit for vandetanib and/or chemotherapy in patients with non-small-cell lung cancer. J Clin Oncol 28: 193-201, 2010.

56. Petreaca ML, Yao M, Liu Y, Defea K and Martins-Green M: Transactivation of vascular endothelial growth factor receptor- 2 by interleukin-8 (IL-8/CXCL8) is required for IL-8/CXCL8-induced endothelial permeability. Mol Biol Cell 18: 5014-5023, 2007.

57. Chen SU, Chou CH, Lin CW, et al: Signal mechanisms of vascular endothelial growth factor and interleukin-8 in ovarian hyperstimulation syndrome: Dopamine targets their common pathways. Hum Reprod 25: 757-767, 2010.

58. Luttun A, Tjwa M and Carmeliet P: Placental growth factor (PlGF) and its receptor Flt-1 (VEGFR-1): Novel therapeutic targets for angiogenic disorders. Ann NY Acad Sci 979: 80-93, 2002 . 